\title{
Diyabet Hastalığı Örneğinde Kronik Hastalar ve Hasta Yakınlarıyla İletişim
}

\section{Communication with Chronic Patients and Patient's Relatives in the Example of Diabetes Disease}

\author{
Izlem Kabalı ${ }^{1}$ (ORCID ID: 0000-0003-4601-7871) \\ Sema Özan² (ORCID ID: 0000-0003-1765-3529) \\ 1'Il Sağlık Müdürlüğü Acil Sağlık Hizmetleri Başkanlığı, Evde Sağlık Hizmetleri Koordinasyon Merkezi, \\ Narlıdere/IZMIR \\ ${ }^{2}$ Dokuz Eylül Üniversitesi Tıp Fakültesi, Tıp Eğitimi AD \\ Sorumlu Yazar: \\ Prof. Dr. Sema Özan, Dokuz Eylül Üniversitesi Tıp Fakültesi, Tıp Eğitimi AD, Balçova/İZMİR \\ e-posta: sema.ozan@deu.edu.tr Tel: 2324124683
}

\begin{abstract}
Anahtar Sözcükler:
Kronik hastalıklar, diyabet, iletişim, tıp eğitimi

Keywords:

Chronic diseases,

diabetes, communication,

medical education

Gönderilme Tarihi

Submitted:12.06.2019

Kabul Tarihi

Accepted: 21.10.2019

Amaç: Kronik hastalar ve yakınları ile iletişimde hekimler için yararlı olacağı düşünülen bilgilerin diyabet hastalığı örneği üzerinden sunulmasıdır.

Gereç ve Yöntem: Geleneksel derleme yöntemi ile hazırlanmıştır. Kronik hastalar ve yakınları ile iletişimin önemi, uygun iletişimin nasıl kurulması gerektiği ve diyabet hastalığı üzerinden örneklendirilmesi literatüre dayanarak açıklanmış ve özetlenmiştir.

Bulgular: Uzun süren ve yavaş ilerleyen hastalıklar olarak tanımlanan kronik hastalıklar 21. yüzyılın en önemli sağlık sorunudur. 2015'te bulaşıcı olmayan hastalık kaynaklı ölümlerin arttığ1 ve \%70’e ulaştığ1 görülmektedir. Kronik hastalıklar sadece gelişmiş ülkelerin sorunu olmaktan çıkmış dünya mortalite ve morbidite verilerine göre tüm ülkelerde birinci sağlık sorunu haline gelmiştir. Kronik hastalıkların tedavi seyrinde hastaların öz bakımları tıbbi tedavi kadar önem taşımaktadır. Kronik hastalar uygun şekilde bilgilendirildikleri ve karar verme sürecine katıldıklarında tıbbi önerilere daha kolay uyum sağlamakta, öz bakımlarını daha fazla sahiplenebilmekte, sağlık çıktılarında iyileşme görülmektedir. Kronik hastalıklar ömür boyu bakım gerektirdiğinden bu süreç hasta yakınları için de zorluklar içermekte, hasta yakınları da fiziksel ve psikososyal sorunlar yaşayabilmekte, desteğe, bakıma gerek duyar hale gelebilmektedir.
\end{abstract}

\section{ÖZET:}

Künye: Kabalı I, Özan S. Diyabet Hastalı̆̆ı Örneğinde Kronik Hastalar ve Hasta Yakınlarıyla İletişim. Tip Eğitimi Dünyası. 2020;19(57):109-119 
Diyabet de sürekli sağlık bakımı gerektiren, en kompleks, en önemli kronik hastalıklardan birisidir ve diğer kronik hastalıklarda olduğu gibi hastalar ve yakınları benzer sorunları yaşayabilmektedir. Diyabet sıklığı 1997'den 2010'a dek \%90 artarak \%7.7'den \%13.7'ye yükselmiştir. Dünyada tüm ölüm nedenleri arasında 8. sırada yer almakta, miyokard enfarktüsü ve inmeye bağlı erken ölümlere neden olmaktadır. 20 yaş üzeri nüfusun \%42.4'ünde diyabet ya da prediyabet olduğu bilinmektedir.

Sonuç: Diyabet dahil tüm kronik hastalıkların yönetiminde, olumlu sonuçlara ulaşmada hekimler ile kronik hastalar ve yakınları arasında kurulacak doğru ve yeterli iletişim en önemli öğeler arasında belirtilmektedir. Gerek mezuniyet öncesi gerekse mezuniyet sonrası tıp eğitiminde bu konuya özel önem verilmesi de konuya ilişkin farkındalığın ve duyarlılığın artırılmasında katkı sağlayacak, uygulamalara olumlu yansımaları olacaktır.

\section{ABSTRACT:}

Aim: The presentation of information that is thought to be useful for physicians in communication with chronic patients and their relatives through the example of diabetes.

Materials and methods: Prepared by the traditional review method. The importance of communication with chronic patients and their relatives, how to establish appropriate communication and sampling through diabetes is explained and summarized based on the literature.

Results: Chronic diseases, defined as prolonged and slowly progressive diseases are the most important health problems of the 21st century. In 2015, non-communicable deaths increased, reaching $70 \%$. Chronic diseases have not only become a problem in developed countries but have become the first health problem in all countries according to world mortality and morbidity data. Self-care of patients is as important as medical treatment in the course of treatment of chronic diseases. When chronic patients are informed and involved in the decision-making process, they can adapt more easily to medical advice, take on more selfcare and their health outcomes improve. Since chronic diseases require lifelong care, this process involves difficulties for relatives of the patients, and their relatives may experience physical and psychosocial problems and may need support and care. Diabetes is one of the most complex, most important chronic diseases that require continuous health care, and, like other chronic diseases, patients and their relatives may experience similar problems. The frequency of diabetes increased by $90 \%$, from $7.7 \%$ to $13.7 \%$ between 1997 to 2010. It ranks 8 th among all causes of death in the world and causes premature deaths due to myocardial infarction and stroke. It is known that $42.4 \%$ of the population over the age of 20 have diabetes or prediabetes.

Conclusions: Correct and adequate communication between physicians and chronic patients and their relatives is among the most important elements in the management of all chronic diseases including diabetes. Giving special attention to this issue in both pre- and post-graduation medical education will also contribute to raising awareness and sensitivity on the subject and will have positive reflections on the practices.

\section{GíRiş}

Kronik hastalıklar 21. yüzyılın en önemli sağlık sorunudur. Dünya Sağlık Örgütü (DSÖ) kronik hastalıkları "uzun süren ve yavaş ilerleyen hastalıklar" olarak tanımlamaktadır (1). Kronik hastalıklarda tıbbi tedavilerle tam bir iyileşme sağlanamamakta, hastanın özbakım sorumluluğunu sahiplenmesi ve sürdürebilmesi 
için periyodik izlem ve destek bakım gerekmektedir $(1,2)$. Sanıldığının aksine, kronik hastalıklar sadece gelişmiş ülkelerin sorunu olmaktan çıkmış dünya mortalite ve morbidite verilerine göre tüm ülkelerde birinci sağlık sorunu haline gelmiştir (3). DSÖ 2008 verilerine göre tüm dünyadaki yaklaşık 57 milyon ölümün 36 milyondan fazlası (\%63) bulaşıcı olmayan hastalıklara bağlıdır. $\mathrm{Bu}$ ölümlerin $\% 80 ‘ \mathrm{i}$ gelişmekte olan ülkelerde gerçekleşmektedir. Nüfus artışı ve ortalama yaşam süresinin uzaması bulaşıcı olmayan hastalıkların görülme sıklığında artışa neden olmakta, buna paralel olarak bu hastalıklara bağlı ölüm oranları da artış göstermektedir (1). 2015'te bulaşıcı olmayan hastalık kaynaklı ölümlerin arttığı, \%70'e (40 milyon) ulaştığ görülmektedir (4). En sık ölüme yol açan ve bulaşıcı olmayan dört kronik hastalık, kardiyovasküler hastalıklar, kanser, kronik solunum yolu hastalıkları ve diyabet olup bunların kronik hastalıklara bağlı tüm ölümler içindeki oranları sırasıyla $\% 45$, $\% 22, \% 10, \% 4$ olarak saptanmıştır (4).

\section{KRONIKK HASTALAR ÍLE İLETIŞiM}

Bireylerin sağlı̆̆1, doğuştan getirdikleri genetik faktörler kadar çevre ile etkileşimlerine de bağlıdır. Bu etkileşimin öneminin fark edilmesi sonrasında sağlığın geliştirilmesi çalışmalarına ağırlık verilmiş, ilgili politikalar ve programlar uygulamaya koyulmuştur. Sağlığı geliştirme programlarının önemli bir bileşeni etkili iletişimdir (5). Günlük yaşamımızın temel bir öğesi olan iletişimde bilgiler kadar duyguların ve düşüncelerin paylaşımı da önemlidir (6). Sağlık alanındaki iletişimin hasta-hekim iletişimi ve toplumsal iletişim olmak üzere iki temel boyutu vardır. Hasta-hekim iletişiminde tıbbi görüşme yani öykü alma klinik uygulamanın temelini oluşturmaktadır. Günümüzde sağlık alanında teknolojik açıdan hızlı bir ilerleme kaydedilmesine rağmen yüz yüze iletişimin sağladığı birçok veriye ulaşılamamaktadır (6). Hekimin iletişim becerilerinin iyi olması hasta memnuniyetinin artmasını sağlamakta, birçok hasta, kaygılarının hekimleri tarafından dinlenmesini beklemektedir (7). 1980'li yıllardan sonra gelişen hasta merkezli yaklaşım ile karar verme sürecine hastanın da dahil edilmesi durumunda sağlık çıktılarının olumlu yönde iyileşme gösterdiği görülmektedir (6). 1981'de kabul edilen Lizbon Hasta Hakları Bildirgesi'nde "hastanın yeterli ölçüde bilgilendirildikten sonra önerilen tedaviyi kabul ya da reddetme hakk1 vardır" ve 1984'de kabul edilen Avrupa Hasta Haklarının Geliştirilmesi Bildirgesi'nde "hastalar durumları ile ilgili tıbbi gerçekler, önerilen tıbbi girişimler ve her bir girişimin potansiyel risk veya yararları, önerilen girişimlerin alternatifleri, tedavisiz kalmanın sonuçları, tanı, prognoz ve tedavinin gidişi konularını içerecek şekilde sağlık durumları konusunda tam olarak bilgilenme hakkına sahiptir" denilmektedir. Hastanın bilgilendirilmesi kadar önemli bir diğer unsur da hasta ile hekim arasında güven duygusuna bağlı bir ilişkinin oluşturulmasıdır. $\mathrm{Bu}$ da hekim ile hasta arasındaki ilişkinin doğru kurulmasından geçmektedir (6).

Hekimin bilgi ve deneyimi ne kadar iyi olursa olsun hasta ile arasındaki iletişimin yeterli olmaması hastanın tedaviye uyumunda istenmeyen durumlara yol açmaktadır. Hastaya ilaçlarını nasıl kullanacağının uygun şekilde anlatılmaması, uygulayacağı diyet hakkındaki bilginin anlaşılır ve açıklayıcı olarak verilmemesi, hasta ile konuşurken teknik terimlerin kullanılması, hastanın anlayıp anlamadığının kontrol edilmemesi, hastadan geribildirim alınmaması gibi iletişim sorunları hastanın aynı ya da farklı hekimlere tekrar tekrar başvurmasına neden olmaktadır (8). 
Hekimler, hastaların ilaç tedavisine ve ilaç dışı tedavilere uyum sağlayamamasını, kronik hastalıkların yönetiminde karşılaştıkları en önemli güçlükler arasında belirtmektedir (\%87). Hastaların düzenli kontrole gelmemesi, SUT'tan kaynaklanan sorunlar, hastaya yeterince zaman ayıramamak ve birinci basamağa gereken önemin verilmemesi ise çok daha düşük oranda (\%13) belirtilen güçlüklerdir (3). Bu bulgular, hastanın tedaviye uyumunda hekim ile hasta arasındaki doğru ve yeterli iletişimin büyük önem taşıdığını düşündürmektedir.

Birçok çalışma hekimlerin iletişim becerilerinin sağlık hizmet kalitesini doğrudan etkilediğini ve arttırdığını göstermiştir. Yetersiz iletişim becerileri sonucunda yanlış tedavi iddiaları, hukuki davalar ve tıbbi hatalar yaşanabilmektedir. Hekimin eğitimi, teknik bilgileri, mesleki tecrübesi ve öngörüleri kadar iletişim becerileri, kendini ifade etme ve empati kurma yeteneği, karşısındakini anlama ve yorum yapma becerisi de hastası ile uyumunu, mesleki tatminini ve iş memnuniyetini arttırmaktadır (9). Hekim ve hasta iletişimi, diyabet, hipertansiyon, konjestif kalp yetmezliği, koroner kalp hastalığ1 gibi yaşam boyu tedavi ve izlem gerektiren kronik hastalıklarda daha da önem kazanmaktadır. Kronik hastalar bilgilendirildikleri ve karar verme sürecine katıldıklarında tıbbi önerilere daha kolay uyum sağlamakta ve öz bakımlarını sahiplenebilmektedirler. Egzersiz, sigara bırakma, beslenme alışkanlıklarının düzeltilmesi gibi sağlıklarıyla ilgili olan, kendileri için zorlu ama yaşamsal önemi olan davranış değişikliklerini daha kolay gerçekleştirebilmektedirler (10).

Kronik hastalıklar, beden yapısındaki fiziksel değişikliklerle birlikte psikososyal sorunları da beraberinde getirebilmektedir (2). Hastalığa bağlı olarak gelişen ağrı, acı, hareket kısıtlılıkları $\mathrm{vb}$ yanında kendi kendine yetememe duygusu, başkalarına bağımlı olma endişesi, depresyon, üzüntü, çaresizlik, kişilerarası ilişkilerde bozulma, ölüm korkusu gibi durumlar kişiyi sosyal hayattan uzaklaştırmakta ve yaşamını zorlaştırmaktadır $(2,11)$.

Kronik hastalıklarda tıbbi tedavinin yanı sira psikososyal tedavi ve bakım da önemli yer tutmaktadır. Psikososyal tedavinin temeli hasta ve yakınlarının hastalığa ve tedaviye uyumunun arttırılması, psikolojik bakımın ilk basamağı da temel iletişim ve tanılama becerileridir (2).

Kronik hastalıkların yönetimi, kişinin hastalığı kabul etmesi, hastalıkla baş etme yollarını benimsemesi açısından da son derece önemlidir ve hastanın tedaviye uyumunu, tedavinin etkinliğini belirleyen temel faktördür (11). Kronik hastalıklarda tedavi ömür boyu süreceği için sadece hekimin değil hastanın ve hatta hasta yakınlarının da sorumluluk alması ve sürece aktif katılımı gerekmektedir (12).

Geleneksel hasta hekim ilişkisinde nelerin konuşulacağına hekim karar vermekte, tıbbi kararları hekim almakta, hastadan bunlara uyması beklenmektedir. $\mathrm{Bu}$ durum hastanın tedaviye niye uymadığı ya da uyamadığıyla ilgili birçok faktörün gözden kaçırılmasına neden olmaktadır. Oysa hastalığı hakkında bilgilendirilen hastaların hayat kalitesi bilgilendirilmeyenlere göre daha yüksek olmakta, karar verme sürecine hastanın da dahil edilmesi sağlık çıktılarının belirgin olarak iyileşmesini sağlamaktadır (12). Kronik hastalıkların yönetilmesinde yararlı bir yaklaşım olarak önerilen "işbirliğine dayalı bakım" modeli iletişimin önemine dayanmaktadır. Modelin uygulanmasında hasta-hekim iletişimi ile ilgili aşağıda özetlenen beş strateji bulunmaktadır (12).

1-Hekim-hasta buluşmasında neler konuşulacağına birlikte karar ver: Hekimlerin çoğunlukla hastası ile ne konuşacağı hakkında 
bir ön hazırlığ1 vardır fakat hastalar bundan haberdar değildir. Görüşmede nelerin konuşulacağını birlikte belirlemek, hastanın gereksinim duyduğu konuların da kapsanmasını ve sürece aktif katılmasını sağlayacaktır.

\section{2-Sor-anlat-sor: Paylaşılacak bilginin} hastanın gereksinimine, koşullarına göre planlanabilmesi açısından önemlidir. Hastaya, "kan şekerinizin düzene girmemesinde nelerin etkili olabileceğini düşünüyorsunuz?” ya da "diyetinizi düzenlemede nasıl zorluklarla karşılaşıyorsunuz?" gibi sorular sorularak alınacak cevaplar, hekimin tedavi planını ve paylaşacağı bilgiyi hastaya göre uyarlamasını sağlayacaktır. Anlatılanların bir kez daha birlikte gözden geçirilmesi de hastanın kendi tedavisi konusunda daha sorumlu davranmasinı ve sahiplenmesini destekleyecektir.

3- Değişime hazır bulunuşluğu değerlendir: Hastalar, önerilen değişikliklerin önemi hakkında bilgilendirilse de alışkanlıklarını değiştirmeye hazır olmayabilirler. Tütün kullanımı, fiziksel aktivite eksikliği, aşırı alkol kullanımı ve sağlıksız beslenme gibi kronik hastalıkların gelişiminden sorumlu birçok alışkanlık değiştirilebilir olan davranışsal risk faktörleridir (13). Kronik hastalardan çoğunlukla yaşam şekillerini değiştirmeleri beklenmektedir. Önemini bilseler de bu değişim onlar için kolay olmayabilecektir. Özellikle geçmişte başarısız deneyimleri varsa yüreklendirilmeleri, kendilerine güvenmelerinin sağlanması önemlidir. Bu noktada, uygun zamanlamalarla ve giderek artan değişimlerin önerilmesi yararlı olacaktır.

4- Özbakım hedeflerini belirle: Hasta için gerçekçi olacak değişiklikleri birlikte belirleyebilmek için SLAM (Specific, Limited, Achievable, Measurable) modeli önerilmektedir. Hedefin özgül olması için hastaya daha fazla egzersiz yapacağının belirtilmesi yetmemeli, haftada kaç gün, kaç dakika, hangi zamanlarda yapacağ1 gibi netlikler sağlanmalıdır. Belirlenen hedefler mümkün oldukça belirsiz bir zamana yayılmamalı, daha sonra güncellenmek üzere, iki ay süre ile ya da bir sonraki görüşmeye dek gibi sınırlar belirlenmelidir. Hedefler hasta için ulaşılabilir olmalı, örneğin o güne dek hiç egzersiz yapmamış bir hastadan haftada beş gün açık havada yürümesi vb beklenmemelidir. Son olarak hedefler ölçülebilir olmalı, hastaya "sık s1k egzersiz yapmalısınız" yerine "haftada 3 gün yarım saatlik yürüyüşler yapmalısınız" ya da “ekmeği azaltması" yerine "her ögünde en fazla bir dilim ekmek yemesi" vb şeklinde öneriler getirilmelidir.

5- Halkayı tamamlama: Hastaların görüşmeden ayrılırken hekimin önerilerini ve önlerindeki zaman içinde neler yapmaları gerektiğini iyi ve doğru anlamış olmaları gerekmektedir. Birçok hastanın hekiminin yanından eksik ya da yanlış bilgilerle ayrıldığı bilinmektedir. $\mathrm{Bu}$ nedenle görüşme sonlandırılmadan önce, önemli noktaları, özellikle vurgulanması gerekenleri birlikte gözden geçirmek hastanın ve/veya yakınlarının tedaviyi doğru şekilde uygulayabilmesi açısından çok değerlidir (12) . Kronik hastalığı olan bireylerin hastalığa uyum çabaları, hastalığın ve hastanın özelliklerinden, aile ortamından, fiziksel ve sosyal çevreden etkilenmektedir (2). Yaşanılan çevrenin kültürel özellikleri bireylerin yaşam tarzlarını, alışkanlıklarını, sağlık davranışlarını etkilemektedir (14). Hastanın cinsiyeti de bu açıdan önemli olmakta, kronik hastanın kadın ya da erkek olması tedaviye ulaşımını, tedavinin gerektirdiği davranış değişikliklerini gerçekleştirip gerçekleştirememesini dolayısıyla tedavinin etkinliğini belirleyebilmektedir (13). Örneğin; kronik hastalıkların daha çok erkeklere özgü olarak görülmesi, geleneksel aile yapısı vb nedenlerle kadınların sağlık hizmetlerine 
ulaşımı ve tedavileri aile büyüklerinin kararına bağlı olabilmekte ve/veya gecikebilmektedir (15). Alkol, sigara kullanımı gibi, aslında sağlığ1 riske atan davranışların erkekler için daha kabul edilir olması da akciğer kanserinin erkeklerde daha fazla görülmesinde etken olabilmektedir (14).

\section{KRONIK HASTA YAKINLARI İLE ILETİ̧̧IM}

Kronik hastaların yaşamlarını kaliteli bir şekilde sürdürebilmeleri için sağlık çalışanlarından aldıkları tıbbi destek yanında yakınlarının onlara verdiği destek de önemlidir. Hasta yakınları 'gayri resmi bakıcı' gibi görünseler de hastanın yaşamı boyunca onunla birlikte olacak, hastalığın tüm evrelerini deneyimleyecek tek ya da birkaç kişidirler (16).

Kronik hastalıklar ömür boyu bakım gerektirdiğinden bu süreçte hasta yakınları da fiziksel ve psikososyal sorunlar yaşayabilmekte, bu açılardan bakıma gerek duyar hale gelebilmekte, çevrelerinden yanlış bilgilendirme ve yönlendirmelere maruz kalabilmektedir (17). Hasta bakmayan yaşıtlarıyla ve hemcinsleriyle karşılaştırıldığında, hastasının bakımını üstlenen hasta yakınlarının ölüm oranlarında artış olduğu da görülmüştür (18). $\mathrm{Bu}$ nedenle hastaların gereksinimleri kadar hasta yakınlarının gereksinimleri de göz önünde bulundurulmalıdır. Sağlık çalışanlarının hasta yakınlarıyla kuracağı etkili ve doğru iletişim bu durumun olumsuz etkilerini ortadan kaldıracaktır (17). Hasta yakınlarına sağlanan destekleyici yaklaşımlar, hem hastaların hem de hasta yakınlarının kronik hastalıkla başa çıkma yeteneğinde artış sağlamaktadır (16).

Bazı kronik psikiyatrik ve nörolojik hastalıklarda hastalar yatağa bağımlı olmadan günlük yaşantısına devam edebilmekte ancak bulundukları sosyal ortamlarda normal dışı davranışlar sergileyebilmektedirler. Bu durum, hasta yakınlarının sosyal hayattan izole olmalarına, depresyona yatkın olmalarına yol açabilmektedir (16). Hasta yakınlarının yaşı, cinsiyeti, sosyoekonomik durumu, eğitim düzeyi, bakıma gönüllü olup olmaması hastanın tedavi ve bakım süreci için önemli ölçütlerdir. Hasta yakınları bazen çaresizlik, öfke, dışlanmışlık vb duygular yaşayabilmektedir (19). Hekim ve sağlık çalışanlarının hasta yakınlarına bu süreçte kendilerinde gelişebilecek psikolojik ve fiziksel hastalıklar konusunda bilgi vermeleri yararlı olacaktır (18).

Ailedeki kronik hastanın cinsiyeti de hastanın bakım kalitesini etkileyebilmektedir. Türkiye'den bir çalışmada çoğu kadının hasta eşlerine bakım vermeyi rutin görevlerinin devamı olarak görmelerine karşın erkeklerin genellikle bu sorumluluktan uzak durdukları bildirilmiştir (19). Hastaya bakım verecek aile yakını ile iletişimde bu tür kültürel, geleneksel öğelerin göz önünde tutulması, motive edici ve yüreklendirici yaklaşımların geliştirilmesi yerinde olacaktır.

Hastalığın doğasına ve evresine bağlı olarak evde bakımı önerilen kronik hastaların izlemleri ve tedavileri doğrudan hasta yakını tarafindan sağlanmaktadır. Ailelerin bakıma dahil edilmesi tedavi uyumunu artırmakta, düzenli doktor kontrolünü sağlamakta ve acil servise başvuru ihtiyacını azaltmaktadır (16). Aile ile kurulan iletişim hastanın sağlığını, güvenliğini, hastaya verilen bakımın kalitesini, hasta yakınlarının memnuniyetini ve ruh sağlı̆̆ını, ayrıca hasta ile ilgilenen sağlık personelinin motivasyonunu da etkilemektedir (20).

Terminal dönem hastalarının yakınlarına yardımcı olabilecek stratejiler içinde, ailelere temelbakım konusundabilgivermek, hastalarıyla nasıl daha iyi iletişim kurulabileceğine ilişsin eğitim vermek de bulunmaktadır. Bunların 
yanında, kendi psikolojik durumlarında da iniş çıkışlar olabileceği gibi manevi doyum da yaşayabilecekleri anlatılmalıdır

Alzheimer'lı hastalar gibi kronik hastaların ya da terminal dönem hastalarının bakımını sağlayanlarda özellikle psikolojik sorunlar görülebilmektedir. $\mathrm{Bu}$ kişilerde depresyon oranının \%40 - \%70 olduğu, bunların \% 50’sinin depresyon tanısını hastalarına bakım verdikleri dönemde aldıkları bildirilmiştir (18). Başka bir çalışmada da ABD'deki Meksika kökenli hasta yakınlarında \%40 oranında depresyon geliştiği gösterilmiştir (19).

Hasta yakınları ile yapılan birçok çalışmanın sonuçları bu kişilerle doğru iletişim kurmanın önemini ortaya koymaktadır. Kalocsai ve arkadaşları hasta yakını aileler ile sağlık çalışanları arasında uygun iletişim kurulabilmesi için "terapötik anlaşma", yaklaşımını önermektedir. Bu yaklaşım iletişim, entegrasyon, birleşme ve yetkilendirme öğelerini içermektedir. $\mathrm{Bu}$ öğeler empatik yaklaşım ve etkili bilgi alışverişi, ailenin sürece dahil edilmesi, tedavi sürecindeki adımlara ilişkin kararlar alınırken ailenin sorumluluk alma konusunda yüreklendirilmesi ve kararların ortak alınarak uygulanması şeklinde özetlenebilir. Tedavi planı ile ilgili açıklamalar ne kadar anlaşılır olursa ve telefonla konuşma, yazışma vb yerine yüz yüze görüşmeler şeklinde yapılırsa o kadar etkili olacak ve aile üyeleri o kadar rahat karar verecektir. Hasta yakınları ile sağlık çalışanları arasında kurulacak güçlü "terapötik anlaşma" hastalığın duygusal kabulünü de kolaylaştıracaktır (20).

İsviçre gibi evde bakım talebinin yüksek olduğu ülkelerde aileler tedavi ekibinin en önemli parçası haline gelmiş, bakımın sağlanamaması durumunda hasta ve toplumun zarar görebileceği düşünülmüştür. $\mathrm{Bu}$ nedenle hekim ve diğer sağlık çalışanlarının hastaya bakım verecek kişilere, hastalarının bakımını sağlayabilmek için gereken becerinin kendilerinde olduğu konusunda güven vermeleri beklenmektedir (18). Kanada'dan bir çalışmada hasta yakınları, hekimlerin kendilerine daha çok tıbbi bilgi verdiğini, hemşirelerin de daha çok duygusal destek konusunda düzenli ve empatik ilişkiye girdiklerini ifade etmişlerdir. Ayrıca, kendilerini çaresiz ve umutsuz hissetmemek için hastalık süresince bilgilendirilmek istediklerini, kendilerine empatik ve anlaşılır yaklaşıldığında ilişki kurmalarının kolaylaştığını, hemşire ve doktorlardan aldıkları cevaplar birbiriyle tutarlı olduğunda kendilerini daha güvende hissettiklerini belirtmişlerdir. Bilinci kapalı hastanın tedavisi sürecinde 'stres ve stresle başa çıkma' konusunda kendilerine yardımcı olunmasından olumlu etkilenmişler, doktorların nasıl olduklarını sormaları, onlara dokunmaları, sandalye vermeleri, su ikram etmeleri gibi hareketlerin kendilerine duygusal anlamda destek sağladığını ifade etmişlerdir (20).

\section{DIYYABET HASTALARI ve YAKINLARI ILE ILETİŞIM}

Diyabet, sağlık bakımı gerektiren en kompleks, en önemli kronik hastalıklardan birisidir ve kronik hastalıklar arasında prevalansı giderek artmaktadır. TURDEP II çalışmasının sonuçlarına göre diyabet sıklığı 13 yılda (19972010 aras1) \%90 artarak \%7.7'den \%13.7'ye yükselmiştir. 20 yaş üzeri nüfusun \%42.4'ünde diyabet ya da prediyabet olduğu bilinmektedir. Diyabet, dünyada tüm ölüm nedenleri arasında 8 . sırada yer almakta, miyokard infartüsü ve inmeye bağlı erken ölümlere neden olmaktadır (21). Diyabetli bireylerde depresyon skoru yüksek bulunmuş, gelişen depresyon ve anksiyetenin yaşam kalitesini olumsuz yönde etkilediği 
belirlenmiştir. Yaşam kalitesinin olumsuzluğu aynı zamanda major depresyona eğilimi de artırmaktadır (14). Uysal ve Akpınar'ın çalışmasında (2013) Tip2 diyabetli hastalarda iletişim bozukluklarının sıkça yaşandığı ve insülin kullanan hasta grubunda depresyon oranının yüksek olduğu tespit edilmiştir (22). Tip2 diyabet hastalığının hastaya, hasta yakınına ve topluma getirdiği ekonomik ve psikolojik yükler hayatlarında uzun sürecek değişimlere yol açmaktadır. Bu değişimlerin neden olduğu psikolojik sorunlar göz önüne alındığında, hasta ve hasta yakınlarıyla iletişimin ne denli önemli ve zor olduğu anlaşılmaktadır (23).

Yaşam tarzındaki olumlu değişiklikler ile prediyabetli kişilerde Tip2 diyabet gelişme olasılığının \%40-58 oranında azalabileceği gösterilmiştir (21). Diyabet hastalarında metabolik kontrolün sağlanması hastalığa ait komplikasyonların önlenmesi açısından önemlidir. Hastanın sağlığı ile ilgili davranışlarının diyabet seyrinde önemli olduğu, psikososyal uyumu iyi olan hastaların metabolik göstergelerinin de iyi olduğu gösterilmiştir (24). Diyabet hastalarında uygun yönlendirme, erken teşhis ve tedavi ile sağlık çıktılarının olumlu yönde etkilendiği görülmektedir (25). Diyabet tedavisinde, hastanın eğitimi, diyet tedavisi ve egzersiz olmak üzere üç basamak önem kazanmaktadır $(21,26)$. Tip2 diyabet hastalarının öz bakım becerilerini doğru olarak kazanmaları ve gerçekleştirmeleri için hastalar tedaviye aktif olarak katılmalıdır. Bunun etkili bir yolu hastalara diyabet hakkında eğitim verilmesidir (27). Diyabet eğitimi, hastaların aktif sorumluluk üstlenmeye teşvik edilmeleri ve desteklenmeleri açısından önemlidir (28). Olgun ve arkadaşlarının çalışmasında (2012), diyabetli hastalarla yürütülen eğitim programının, hastaların sağlıklarına dair inanç ve umutlarını arttırdığını, dolayısıyla hastalığın seyrini olumlu etkilediğini göstermiştir (29).

Adolesan diyabet hastalarını kapsayan bir örnekte, aileniniletişim veproblem çözme, kişisel ve ailesel sorunlarla başa çıkma becerilerini olumlu yönde geliştirmek üzere 'zaman kısıtlı terapötik müdahaleler” önerilmektedir. Diyabet ve kanser hastalarının yakınlarına yönelik bu tarz müdahalelerin hastalarda anlamlı ve olumlu yönde değişimlere yol açtığı görülmektedir. Aile üyelerinin hasta bakımına ve rehabilitasyonuna katılması hastanın işlevlerinin iyileşmesinde önemli oranda yarar sağlamaktadır. Diyabet takip ve tedavisini etkileyebilecek faktörler arasında, yaşam tarzı, kültürel, psikososyal, eğitim ve ekonomik faktörler yer almaktadır. Diyabet tedavisinde önemli bir yere sahip olan beslenme önerileri bireysel gereksinimlere, hastanın alışkanlıklarına, yaşam tarzına, bireyin değişiklikleri yapabilme yeteneğine ve değişim istekliliğine uygun olarak belirlenmelidir (16,30).

Sağlık personelinin kültürel farkındalığının yüksek olması, hastaların kültürel farklılıklarını göz önünde bulundurmaları ve buna uygun bakım vermeleri gerekmektedir. Tüm kronik hastalıklarda olduğu gibi, diyabet hastalığının seyrinde etnik köken de diğer önemli bir etkendir. Diyabet hastalığının yaygın olduğu, bakım kaynaklarına ulaşımda sınırlılık gözlemlenen ve sağlık çalışanları ile iletişimde büyük ölçüde sorunlar tespit edilen Roman halkında diyabet hastalığının yönetiminde sorunlar yaşandığı görülmüştür (14). Etnik köken dışında hastanın cinsiyeti de önem kazanabilmektedir. Gerek dini yönlendirmeler, gerek geleneksel aile yapısı vb nedenlerle kadının çalışması ya da dışarıya çıkması kısıtlanabilmekte bu durum diyabetli kadının fiziksel aktivite ve egzersiz olanaklarını k1sitlayabilmektedir $(14,15)$. 
Çalışmalar, sağlık çalışanlarının, diyabet hastalarının günlük yaşam tarzlarına ve kültürlerine uygun tedavi ve bakım süreçleri geliştirmelerinin önemini ortaya koymaktadır. Hastaların davranış değiş̧ikliği oluşturabilmeleri için onların güveni kazanılmalı ve bilgi paylaşımları onların anlayacağı bir dille yapilmalidır (14).

Sonuç olarak, diyabet gibi yaşam boyu tedavi ve izlem gerektiren kronik hastalıklarda hekim ve hasta iletişiminin büyük önemi olduğu görülmektedir. Kronik hastalar ve hasta yakınları uygun şekilde bilgilendirildikleri ve karar verme sürecine katıldıklarında tıbbi önerilere daha kolay uyum sağlamakta, metabolik göstergelerinde iyileşmeler görülmekte ve öz bakımlarını daha kolay sahiplenebilmektedirler. Gerek mezuniyet öncesi gerekse mezuniyet sonrası tıp eğitiminde bu konuya özel önem verilmesi konuya ilişkin farkındalı̆̆ın ve duyarlılığın artırılmasında katk1 sağlayacak, uygulamalara da olumlu yansımaları olacaktır.

Teşekkür: DEÜTF Dahili Tıp Bilimleri Bölümü Nöroloji Anabilim Dalı Klinik Nörofizyoloji Bilim Dalı öğretim üyesi Prof.Dr. Görsev Yener'e klinik deneyimleri doğrultusunda vermiş olduğu katkılarından dolayı teşekkür ederiz.

\section{KAYNAKLAR}

1. Global Status Report on Noncommunicable Diseases 2010, Burden: Mortality, Morbidity and Risk Factors. World Health Organization. Reprinted 2011. Haziran, 10, 2019 tarihinde https://www.who.int/nmh/publications/ncd report_full_en.pdf adresinden alındı.

2. Özdemir, Ü., Taş̧̧ı, S., (2013). Kronik hastal1klarda psikososyal sorunlar ve bakım. Erciyes Üniversitesi Sağlık Bilimleri Fakültesi Dergisi, 1(1), 57-72.

3. Türkiye kronik hastalıklar ve risk faktörleri sıklığı çalışması. Kasım, 29, 2018 tarihinde https://sbu.saglik.gov.tr/ekutuphane/Yayin/462 adresinden alındı.

4. World health statistics 2017: monitoring health for the SDGs, Sustainable Development Goals ISBN 978-92-4-156548-6. Haziran 10, 2019 tarihinde,

https://apps.who.int/iris/bitstream/hand le/10665/255336/9789241565486-eng.

5. Fertman, C., Allensworth, D.,(2012). Sağlığı geliştirme programları. Kasım, 3 2018 tarihinde https://dosyamerkez.saglik. gov.tr/Eklenti/30355, sagligi-gelistirmeprogramlaripdf.pdf?0 adresinden alındı.

6. Özçakır, A., (2004). Hekim-hasta ilişskisi: karar verme sürecinde hastanın yeri. Türkiye Klinikleri Journal of Medical Sciences, 24, 411415

7. Simpson, M., (1991). Doctor-patient communication. British Medical Journal, 13851387

8. Bol, P., Gül, G., Erbaycu, A.E.,(2013). Hasta hekim iletişimindeki eksiklikler ve hataların ortaya konmasinda FMEA model analizinin katkısı. İzmir Göğüs Hastalıkları Dergisi, 17, 181-191

9. Özer, O., (2007). Şişli etfal eğitim araştırma hastanesi polikliniklerine başvuran hastalarla yapılan anket çalışması ile hasta hekim 
iletişiminin incelenmesi. Uzmanlık tezi. Şişli Etfal Eğitim ve Araştırma Hastanesi, Aile Hekimliği Koordinatörlüğü, İstanbul,

10. Beck, R.S., Daughtridge, R., Sloane, P.D., (2002). Physician-patient communication in the primary care office: a sistematic review. Journal of American Board of Family Medicine, 15(1), 25-38

11. Sayg1lı D.D. Kronik Hastalıklar ve Psikolojik Sağlık, Herkese Bilim Teknoloji Dergisi, Ocak, 26, 2018, say1 96:23

12. Boxer, H., Snyder, S., (2009). Communication strategies to promote selfmanagement of chronic illnes, Mart, 26, 2018 tarihinde https:/www.aafp.org/fpm/2009/0900/ p12.pdf adresinden alındi.

13. Türkiye Bulaşıcı Olmayan Hastalıklar Çok Paydaşlı Eylem Planı 2017-2025. Şubat, 26, 2019 tarihinde,

https://sbu.saglik.gov.tr/Ekutuphane/Home/ GetDocument/547 adresinden alındı.

14. Kaymak, Ö. G., (2018).Yaygın görülen kronik hastalıklarda kültürel farkındalık. Journal of Awareness, 3(özel), 715-721.

15. Ünal B. Toplumsal cinsiyet ve bulaşıcı olmayan hastalıklar. Ed: Akın A, Özpınar S. Toplumsal cinsiyet ve kadın sağlığı. Nobel akademik Yayıncılık Danışmanlık Tic. Lit. Şti., Ankara, Aralık 2018;225-236

16. Shields, G.C., Finley, A.M., Chawla, N., (2012). Couple and family intervetions in health problems, Journal of Marital and Family Therapy, 38(1), 265-280
17. Milli Eğitim Bakanlığı Sağlık Hizmetleri, Sağlıkta İletişim Sayfa 19. Mart, 202018 tarihinde http://www.megep.meb.gov.tr/mte_program modul/moduller/Sa\%C4\%9Fl\%C4\%B1kta $\% 20$ $\%$ C4\%B0leti $\%$ C5\%9Fim.pdf adresinden alındı.

18. Zarit, H. S., (2004). Family care and burden at the and of life. Canadian Medical Association or its Licensors, 170(12),1811-1812.

19. Atagün, M.İ., Balaban D.Ö., Atagün, Z., (2011). Kronik hastalıklarda bakım veren yükü, Psikiatride Güncel Yaklaşımlar, 3(3), 513-552

20. Kalocsai, C., Amaral, A., Piquette, D., (2018). "It's beter to have three brains working instead of one": a qualitative study of building therapeutical laince with family members of critically ill patients; BioMed Central Healt Services Research 18:533

21. Türkiye Diyabet Programı 2015-2020 TC Sağlık Bakanlı̆̆ı. Ocak, 20, 2019 tarihinde https://www.diyabetimben.com/wpcontent/ uploads/2014/11/turkiyediyabetprogrami.pdf adresinden alındı.

22. Uysal, Y., Akpınar, E., (2013). Tip 2 Diyabetli Hastalarda Hastalık Algısı ve Depresyon, Çukurova Üniversitesi Tıp Fakültesi Dergisi, 38, 31-40.

23. Orhan, B., Bahçecik, N., (2018). Tip 2 diyabetli bireylerin mobil uygulama eğitimi hakkındaki görüşleri, Sağlık Akademisyenleri Dergisi,5(2), 130-134.

24. Kara, K., (2011). Diyabette bakım profili ile metabolik kontrol değişkenleri arasındaki ilişkiler; Kafkas Journal of Medical Sciences, 1(2), 57-63 
25. Başer, D.A., Kahveci, R., Aksoy, H., (2014). Tip 2 diyabetli hastaların aile hekimleriyle iletişimi ile ilgili görüş ve deneyimleri: kalitatif çalışma: Cumhuriyet Tıp Dergisi, 36, 495-502

26. Okburan, G., (2018). Tip 2 diyabet tedavisinde yaşam tarzı değişiklikleri- beslenme ve fiziksel aktivite. Beslenme Diyabet Dergisi, 46(3), 294-302.

27. Powers, M.A., (2017). Diabetes selfmanagement education and support in type 2 diyabetes. Clinical.Diabetes Journals.Org, 43, 70-80.

28. Davies, M.J., Heller, S., (2008). Effectineness of the diabetes education and self management for on going and newly diagnosed (DESMOND) programme for people with newl diagnosed type 2 diabetes: cluster randomised controlled trial. British Medical Journal, 336(7642),491-495.

29. Olgun, N., Akdoğan A.Z., (2012). Sağlık inanç modeli doğrultusunda verilen eğitimin diyabet hastalarının bakım uygulamalarına etkisi. Sağlık Bilimleri Fakültesi Hemşirelik Dergisi, 46-57 Ocak, 202019 tarihinde http:// www.hacettepehemsirelikdergisi.org/pdf/pdf_ HHD_143.pdf adresinden alınd1

30. TEMD Diabetes Mellitus ve Komplikasyonlarının Tan1, Tedavi ve İzlem Kilavuzu, 2018. Ocak, 212019 tarihinde http://temd.org.tr/admin/uploads/ tbl_kilavuz/20180814161019-2018tbl kilavuz6c373c6010.pdf adresinden alınd1. 